\author{
Review Article
}

\title{
ROLE OF AYURVEDIC ANTICOAGULANT AND ANTIOXIDANT TREATMENT IN COVID 19
}

\author{
Amrut.S. Salunke1, Adarsh Ramkalap Sharma ${ }^{2 *}$, Sonali Sunil Tadasarkar² \\ ${ }^{*}$ H.O.D \& Associate Professor, ${ }^{2}$ Final year P.G. Scholar, Dept. of Shalakyatantra, R.A.Podar Medical (Ayu) College \\ and M.A.Podar Hospital, Worli, Mumbai, India.
}

\section{Article info}

Article History

Received: 18-05-2021

Revised : 01-06-2021

Accepted: 10-06-2021

Published: 18-09-2021

KEYWORDS:

COVID-19,

Ayurveda,

Anticoagulant,

Immunomodulatory,

Antioxidant

\begin{abstract}
Corona virus disease is caused by severe acute respiratory syndrome Corona virus 2 [SARSCoV-2] infections attacking multisystem of the human body at a time, of which respiratory system, immune system and circulatory system are most affected. The complications of the disease arise or it becomes more pronounced, after the cytokinine storm phase becomes established leading to hypercoagulative state affecting the circulatory and respiratory system. In Ayurveda, there is a holistic approach in treating the disease and the body as a whole. Drugs such as Haridra, Tulasi, Guduchi, Yashtimadhu, Twak, Triphala, Lavang, Maricha, Pippali etc and few Visha Dravyas like Langali, Dravanti etc can be used a single drug or a group of drugs with their phytochemical properties and active principles leading to delay and prevention of hyper coagulable states thereby preventing the cascade of complications caused by COVID, additionally having anti-inflammatory and immune-modulatory effect. Scientific research on these drugs may reveal a new approach for management and prevention of COVID related complications and can be a subject of future research interest.
\end{abstract}

\section{INTRODUCTION}

Coronavirus disease 2019 (COVID-19) is caused by (SARS-CoV-2) severe acute respiratory syndrome infection mainly targeting the immune system of the body. In December 2019, its outbreak occurred in Wuhan city, Hubei province, China which further got spread worldwide.[1]

AIM

To review research which has already been conducted and currently carried out on different herbal plants for their anticoagulant property which might have a possible application in the prevention and treatment of Covid-19 and related complications.

\section{OBJECTIVES}

- To study patho-physiology of Covid-19 in both Ayurvedic and modern aspects.

- To quantify the use of Ayurvedic anticoagulant drugs with antioxidant property and its role in breaking patho-physiology of Covid-19 and its adjunct use for treating with post COVID complications and effects.

\begin{tabular}{|c|l|}
\hline \multicolumn{3}{|c|}{ Access this article online } \\
\hline Quick Response Code & \\
\hline &
\end{tabular}

\section{MATERIALS AND METHODS}

- The published literature about COVID 19.

- Ayurvedic Nighantus, standard textbooks and their commentaries.

- Scholarly articles written and published on various internet platforms related to COVID 19 and its Ayurvedic treatment were reviewed.

Patho-physiology of Covid-19 According to Modern and Ayurvedic Aspects

Severe acute respiratory syndrome corona virus 2 (SARS-CoV-2) causes COVID-19, a respiratory pandemic. It has 96.2 percentage structural similarity with bat corona virus and 79.5 percent similarity with severe acute respiratory syndrome corona virus.[2] Corona viruses have a single-stranded RNA genome covered by an enveloped structure. Size ranges from 26.2 to 31.7 kilo bases and 50 to 200 nanometers in diameter which is largest for any RNA viruses. SARSCoV-2 spike protein directly binds with the host cell surface ACE2 receptor facilitating virus entry and replication.[3] SARS-CoV-2 uses ACE2 as a cellular entry receptor and compared to SARS-COV has 10 to 20 times more affinity leading to increase chances of human to human transmission. ${ }^{4]}$

Types of COVID variants found in India: UK variant [B.1.617], South Africa variant [B.1.351], Brazil variant [P1 variant]. Among all the mutant COVID-19 
variants in India, of all double mutated virus B.1.617 is becoming the most prevalent according to genome sequencing data submitted by Indian scientists to a global database. The B.1.617 variant contains mutations from two separate virus variants- E484 and L452R.

SARS-CoV-2 mainly alters immune regulatory mechanism and damage immune homeostasis, [5] the immune response of this infection occurs in two phases:

\section{Defense Phase}

When aerolised uptake of SARS-CoV-2 enters in lungs leads to infection of ACE2 expressing target cells such as alveolar type 2 cell. This generates antibody secreting cells, helper T-cells, activated CD4, CD8, T cells that bind to this virus. The innate immune response against viral infection relies on the interferon type 1 and controls replication of the virus. SARS-COV and SARS-COV-2 share the same cell receptor in the human entry as angiotensin converting enzyme 2 but MERS-COV uses another specific receptor di-peptidyl peptidase and amino peptidase N. ${ }^{6]}$

\section{Damage Phase}

It leads to the uncontrolled release of cytokines that causes cytokine storm or cytokine release syndrome (CRS) characterized by increased interleukin 2, interleukin 7, interferon- gamma, tumor necrosis factor etc. CRS damages the tissues of lungs, kidney and heart likely leading to severe complications like ARDS, respiratory failure and even death. Cytokine storm and lymphopaenia may have a significant role in the pathogenesis of COVID infection. ${ }^{7]}$

Cytokines are further divided into TH1 and TH2 and they are the hormonal messengers responsible for immune response.

Common clinical features of COVID19 includes fever (99\%), dry cough (60\%), myalgia (44\%), fatigue $(70 \%)$ and breathlessness still in advanced stages may cause (acute respiratory distress syndrome) ARDS, kidney failure and even death. ${ }^{[8]}$
A new variant symptom includes abdominal pain, diarrhea, unexplained headache, conjunctivitis or pink eyes, extreme headache or acute pain above eyelids and confusion of the brain - brain fog.

Ideal laboratory confirmation of a suspected case includes nasopharyngeal and oro-pharyngeal swab. Nasopharyngeal swabs become the preferred swab as it is better tolerated, safe to operate.[9] At present confirmation of COVID -19 cases is based on RT-PCR [real time reverse transcriptase polymerase chain reaction] by confirmation by nucleic acid sequencing.[10]

\section{Patho-physiology of Covid-19 According to Ayurveda}

It is evident that Covid-19 is known to trigger inflammatory pathways and subsequent cytokine storm leading to multiple organs dysfunction (MOD) and failure. Viral infections are always being considered as manifestation of Pitta Dosha vitiation in Ayurveda's paradigm. Pitta Dosha is characterized by properties heat, sharpness, pungency and liquid form in normal state.

Hypothetically, like Herpes Zoster and Chickenpox if it is believed that SARS-CoV-2 is also creating an imbalance in Pitta Dosha and allowing body heat to exacerbate causing damage to tissues then the clinical picture fits into this pathology.

Aggravated heat from vitiated Pitta leads to triggering of inflammatory pathways which may be causing initial symptoms of Covid-19 such as dryness initially leading to weakness, malaise, body ache and fever. Pitta vitiation possibly results in the disruption of the immune-regulatory molecules skewed towards the unregulated trigger of pro-inflammatory cytokines facilitating more cytokine release and viraemia resulting in cytokine storm leading to MODS.

Aggravation of Pitta allowing dryness and raised temperature to manifest aggravated heat has a strong potential to attract the moisture from the healthy tissues causing excess accumulation of water content, accumulated water allows Kapha to increase due to homologous nature.[11]

DISCUSSION

\begin{tabular}{|l|l|l|}
\hline Drug/ Dravya & Properties & Additional properties \\
\hline Haridra & $\begin{array}{l}\text { Rasa: Tikta, Katu Guna: Ruksha, Laghu } \\
\text { Veerya: Ushna Vipaka: Katu }\end{array}$ & $\begin{array}{l}\text { Raktaprasadan, Raktavardhak, Kaphaghna, } \\
\text { Jwaraghna, Peenasa Aruchi-nashan }{ }^{[12]}\end{array}$ \\
\hline Twak & $\begin{array}{l}\text { Rasa: Tikta, Katu, Madhur } \\
\text { Guna: Ruksha, Laghu, Tikshna } \\
\text { Veerya: Ushna Vipaka: Katu }\end{array}$ & $\begin{array}{l}\text { Kaphavatashamak, Yakshmanashak, } \\
\text { Aruchi-nashan, Peenasa Kasajit }\end{array}$ \\
\hline Yash] $]$ \\
\hline Tulasi & $\begin{array}{l}\text { Rasa: Madhur Guna: Guru, Snigdha } \\
\text { Veerya: Sheeta Vipaka: Madhur }\end{array}$ & $\begin{array}{l}\text { Kshayapaha, Contains Glycosides: } \\
\text { liquiritin, isoliquiritin.[14] }\end{array}$ \\
\hline $\begin{array}{l}\text { Rasa: Tikta, Katu } \\
\text { Guna: Ruksha, Laghu }\end{array}$ & $\begin{array}{l}\text { Hridya, Raktashodhak, Deepan, Pachan, } \\
\text { Anuloman, Kasashwasahar, Kshayanashak, }\end{array}$ \\
\hline
\end{tabular}




\begin{tabular}{|l|l|l|}
\hline & $\begin{array}{l}\text { Veerya: Ushna Vipaka:Katu } \\
\text { Prabhav : Bhutaghni }\end{array}$ & $\begin{array}{l}\text { Jwaraghna, Sheetaprashaman[15] } \\
\text { Antioxidant properties: Improves humoral } \\
\text { and cellular immunity[16,46] }\end{array}$ \\
\hline Lavang & $\begin{array}{l}\text { Rasa: Tikta, Katu } \\
\text { Guna: Laghu, Snigdha } \\
\text { Veerya: Sheeta Vipaka: Katu }\end{array}$ & $\begin{array}{l}\text { Aampachak, Jwaraghna, Ruchikar, Kasa } \\
\text { Shwasa Hikka Kshayanashak. }{ }^{[17]}\end{array}$ \\
\hline Marich & $\begin{array}{l}\text { Ras: Katu. Guna: Laghu, Tikshna } \\
\text { Veerya: Ushna. Vipaka: Katu }\end{array}$ & $\begin{array}{l}\text { Swedajanan, Kapha nissaarak, Kaphaghna, } \\
\text { Vishamjwaranashak }{ }^{[18]}\end{array}$ \\
\hline $\begin{array}{l}\text { Rasa: Kashay, Tikta } \\
\text { Guna: Ruksha,Laghu } \\
\text { Veerya: Ushna, Vipaka: Katu }\end{array}$ & $\begin{array}{l}\text { Kaphapittashamak, Uttejak, Hridya, } \\
\text { Shonitasthapak, Jwaraghna }{ }^{[19]}\end{array}$ \\
\hline
\end{tabular}

\begin{tabular}{|l|l|l|}
\hline Drug/Dravya & Properties & Additional properties \\
\hline Langali & $\begin{array}{l}\text { Rasa: Tikta, Katu } \\
\text { Guna: Laghu, Tikshna } \\
\text { Veerya: Ushna Vipaka: Katu }\end{array}$ & $\begin{array}{l}\text { Shleshmajit, Raktashodhak, Vishamjwaranashak }{ }^{[20]} \\
\text { Latex have anticoagulant and anti-fibrinogenolytic } \\
\text { property[21] }\end{array}$ \\
\hline Dravanti & $\begin{array}{l}\text { Rasa: Katu } \\
\text { Guna: Ruksha, Guru, Tikshna } \\
\text { Veerya: Ushna Vipaka: Katu }\end{array}$ & $\begin{array}{l}\text { Sarvangashothahar, Rechak[22] } \\
\text { Latex when diluted delays clotting time or hampers } \\
\text { clot formation[23] }\end{array}$ \\
\hline Kumbhi & $\begin{array}{l}\text { Rasa: Katu Guna: Ruksha } \\
\text { Veerya: Ushna Vipaka: Katu }\end{array}$ & Anticoagulant properties ${ }^{[24]}$ \\
\hline Guduchi & $\begin{array}{l}\text { Rasa: Katu, Tikta, Kashay } \\
\text { Guna: Laghu, Veerya:Ushna } \\
\text { Vipaka: Katu }\end{array}$ & $\begin{array}{l}\text { Rasayan, Balya, Agnideepan, Tridoshashamak, Daha } \\
\text { Prameha Kasa Panduhar }{ }^{[25]}\end{array}$ \\
\hline Pippali & $\begin{array}{l}\text { Rasa: Katu Guna: Snigdha, Laghu } \\
\text { Veerya: Anushna Vipaka: Madhur }\end{array}$ & $\begin{array}{l}\text { Rasayani, Rechani, Agnivardhak, Vrishya, Medhya, } \\
\text { Jeernajwarahar, Medakaphanashan with honey[26] }\end{array}$ \\
\hline Sunthi & $\begin{array}{l}\text { Rasa: Katu Guna: Laghu } \\
\text { Veerya: Ushna Vipaka: Madhur }\end{array}$ & Vibandhabhedini, Kasahar, Hrudayaamayhar[27] \\
\hline Vantrapushi & $\begin{array}{l}\text { Rasa: Tikta, Katu } \\
\text { Guna: Ruksha, Laghu, Tikshna } \\
\text { Veerya: Ushna Vipaka: Katu }\end{array}$ & Sara, Tivrarechini, Pittaraktashodhan[28] \\
\hline Sadapushpa & $\begin{array}{l}\text { Rasa: Kashay, Tikta Guna: } \\
\text { Ruksha, Laghu } \\
\text { Veerya: Ushna Vipaka: Katu }\end{array}$ & $\begin{array}{l}\text { Vatakaphashamak, Hridya, } \\
\text { Raktabharadhikyanashini[29] }\end{array}$ \\
\hline
\end{tabular}

\section{Properties of Triphala}

1. Hypercholesteremic effect

2. Anti-inflammatory effect

3. Gastrointestinal effect

4. Stress reducing effect

5. Anti obesogenic effect

6. Antidiabetic effect

7. Anti-neoplastic effect

8. Anti-immunosenescence effect

9. Immuno-modulating effect

10. Analgesic effect

11. Bronchodilator effect

12. Increases red blood cells and hemoglobin production. ${ }^{[30]}$

\section{Haridra (Curcuma longa)}

Potential benefits of alkaloids derived from turmeric have shown strong potentially inhibitory effects on the neuraminidases from two influenza viral strains.[31] It also possesses anti-viral properties by boosting the immune system. ${ }^{[32]}$ It even holds skin improving and memory enhancing properties[33]. It also works as natural anti-inflammatory drug along with other herbs.[34] Turmeric also possesses antiinflammatory and immune modulatory properties.[35]

\section{Guduchi}

Guduchi (Tinospora cordifolia (Willd.) Miers) One of the best Rasayana dravya also known as "Amrita" have immuno-modulatory property and 
enhances innate immunity against infections. Tinosporin, diterpenoid as active principles have antiviral properties, can be used for the treatment of retroviruses[36]. Aqueous extracts of T. cordifolia influences the cytokinine production and enhances activation of immune cells[37]. It is a potent hepatoprotective drug hence effective in preventing hepatotoxicity. It enhances vitamin $\mathrm{C}$ level thereby acting as an antioxidant[38]. Stem bark has immunomodulatory activity leading to increased phagocytic activity and macrophages [39].

\section{Yashtimadhu}

Mulethi (Glycyrrhiza glabra L.) Major photo component reported in Yashtimadhu is glycyrrhizin which is a promising candidate in inhibiting replication of the SARS- associated virus ${ }^{[40]}$. It also improves the resistance against the herpes simplex virus type 1 (HSV-1) by Type I and II interferons (IFN) and Th2 cytokines secretion.[41] It has anti- viral activity against Human Immunodeficiency Virus (HIV), potent immunomodulator and has antioxidant activity ${ }^{[42] .}$

\section{Tulasi}

Tulasi (Ocimum sanctum L.) regarded as mother medicine of nature shortens the course of all illness. Tulasi has anti- bacterial, anti-viral and antifungal activity. ${ }^{43]}$ Flavonoids present in the extracts of Tulasi leaves, is found to be responsible for the immunomodulatory properties by increasing the level of IL-4, natural killer cells and helper cells. ${ }^{[44]}$ Essential oils like Eugenol in leaves produce anti-viral activity against different viruses e.g. polio virus type 3 , herpes virus (HSV), hepatitis B virus etc. ${ }^{[45]}$ Ethanolic extract of Tulasi plant leaves in a range of $22.5 \mathrm{mg} / \mathrm{ml}$ concentration inhibits replication of polio type 3 virus. Extracted components of Tulasi like linalol and ursolic acid has shown broad- spectrum antiviral activity against RNA virus and adenoviruses.[46]

\section{Lavang}

Clove (Syzygium aromaticum) is one of the most valuable spices used for many centuries as food preservative and medicinal purposes. It represents one of the richest sources of phenolic compounds like eugenol, eugenol acetate and gallic acid. This plant's antioxidant and antimicrobial activity is higher than many other spices, vegetables and fruits. [47]

\section{Marich}

Piper nigrum is utilized extensively due to its antioxidant, antitumor, anti-allergic, antiinflammatory, gastrointestinal protection and antidiarrheal properties.[48]

Twak

Cinnamon is an unusual tropical plant belonging to the Lauraceae family. It has been used for hundreds of years as a flavor additive, but it has also been used in natural Eastern medicine. Cinnamon extracts are vital oils that contain biologically active compounds, such as cinnamon aldehyde, cinnamic alcohol, cinnamic acid, and cinnamate. It has antioxidant, anti-inflammatory, and antibacterial properties and is used to treat diseases such as diabetes and cardiovascular disease.[49]

\section{Sunthi}

Ginger (Zingiber officinale) has hypolipidemic, antiemetic and chemoprotective action. It also possesses properties like antiviral, anti-inflammatory and antiulcerogenic.[50]

\section{Pippali (Piper longum L.)}

Pippali Rasayana, a famous Ayurvedic preparation, reported having significantly activated macrophages in an experimental study on mice. Administration of $P$. longum extract and its phytochemical piperine increased the total WBC count, Bone marrow cellularity and $\alpha$-esterase positive cells in mice. [51] Immunomodulatory action of Pippali fruits (via modulation of both specific and non-specific immune response) has been reported by using macrophage migration index (MMI), haemagglutination titre (HA) and phagocytic index (PI) in mice. The effect was more prominent at a lower dose $(225 \mathrm{mg} / \mathrm{kg})$ and was marginally reduced when the dose was increased.[52]

\section{Naagkeshar}

Mesua ferrea leaves contains phenolic, alkaloid content such as ethanol, methanol, ethyl acetate and hexane extracts all having antioxidant properties. Of the 4 extracts ethanol extract showed better antioxidant property.[53]

\section{CONCLUSION}

The drugs which are discussed above, few of them being Vishadravya like Langali, Dravanti should be used with great care along with the remaining drugs. Since these drugs also have abortifacient properties, its dosage and use should be carefully monitored. Due to their Rasapanchak properties and active constituents, they can be used in animal trials to examine the effect of their anticoagulant and antiinflammatory property on cytokinine storm so that its progression to multi organ system dysfunction and failure can be abruptly stopped and the complications of COVID 19 and its severity can be reduced and prevented. Separate and combined drug trials with various permutations and combinations can be carried to rule out the efficacy of above mentioned drugs in COVID 19 with a view to make this world, a better place for living and making it disease-free.

\section{REFERENCES}

1. Sahasranaman A, Kumar N. Network structure of COVID-19 spread and the lacuna in India's testing strategy. Available at SSRN3558548. 2020. https:// doi.org/10.2139/ssrn.3558548 
2. Nikhat S, Fazil M. Overview of COVID-19; its prevention and management in the light of Unani medicine. Science of the Total Environment. 2020. Vol.728:138859. https://doi.org/10.1016/j. scitotenv. 2020.138859

3. Yang $\mathrm{H}$, Bartlam M, Rao Z. Drug design targeting the main protease, the Achilles' heel of coronaviruses. Current Pharmaceutical Design. 2006; 12(35): 4573-90. https://doi.org/10.2174/ 138161206779010369

4. Zhang H, Penninger JM, Li Y, Zhong N, Slutsky AS. Angiotensin- converting enzyme 2 (ACE2) as a SARS-CoV-2 receptor: molecular mechanisms and potential therapeutic target. Intensive Care Medicine. 2020; 46(4):586-90. https://doi.org/ 10.1007/s00134-020-05985-9

5. Patwardhan B, Chavan-Gautam P, Gautam M, Tillu G, Chopra A, Gairola S, et al. Ayurveda rasayana in prophylaxis of COVID- 19. Curr Sci. 2020; 118: 1158-60.

6. Kindler E, Thiel V, Weber F. Interaction of SARS and MERS coronaviruses with the antiviral interferon response. Adv Virus Res. 2016; 96:21943. https://doi.org/10.1016/bs.aivir.2016.08.006

7. Wong CK, Lam CW, Wu AK, Ip WK, Lee NL, Chan IH et al. Plasma inflammatory cytokines and chemokines in severe acute respiratory syndrome. Clinical \& Experimental Immunology. 2004; 136 (1): 95-103. https://doi.org/10.1111/j.1365-2249. 2004.02415.x

8. Huang C, Wang Y, Li X, Ren L, Zhao J, Hu Y, et al. Clinical features of patients infected with 2019 novel coronavirus in Wuhan, China. The Lancet. 2020; 395(10223): 497-506. https://doi.org/10. 1016/S0140-6736(20)30183-5

9. Tang YW, Schmitz JE, Persing DH, Stratton CW. Laboratory diagnosis of COVID-19: current issues and challenges. Journal of Clinical Microbiology. 2020; 58 (6); 12-20. https://doi.org/10.1128 /JCM. 00512-20

10. Padhi A, Kumar S, Gupta E, Saxena SK. Laboratory diagnosis of novel coronavirus disease 2019 (COVID-19) infection. In: Coronavirus Disease 2019 (COVID-19) 2020 (pp. 95-107). Springer, Singapore. https://doi.org/10.1007/978-981-154814-7_9

11. Mahesh S. et. al, pathophysiology of covid-19 and possible management principle from Ayurveda's perspective, Annals of Ayurvedic Medicine Vol-9 Issue-3 Jul.-Sep., 2020

12. Acharya Priyavrat Sharma, Dravyaguna Vigyan, dwitiya adhyaya chakshushyadivarga, Published by Chaukhambha Bharati Academy Reprint 2015. pg no. $163,164$.

13. Acharya Priyavrat Sharma, Dravyaguna Vigyan, Chaturtha Adhyayachedanadi (shleshmahar) varga,
Published by Chaukhambha Bharati Academy Reprint 2015.pg no.250-252.

14. Acharya Priyavrat Sharma, Dravyaguna Vigyan, chaturtha adhyayachedanadi (shleshmahar) varga, Published by Chaukhambha Bharati Academy Reprint 2015. pg no.253, 254.

15. Acharya Priyavrat Sharma, Dravyaguna Vigyan, panchamadhyaya deepanadivarga, Published by Chaukhambha Bharati Academy Reprint 2015. pg no.513-515.

16. Sai S, Srilatha G et al., Ayurveda's Holistic Lifestyle approach for the management of covid-19 possible role of Tulsi, International Journal of research in Pharmaceutical Sciences 2020,11,p.16-18. https:// doi.org/ 10.26452/ijrps.v11iSPL1.1976

17. Acharya Priyavrat Sharma, Dravyaguna Vigyan, chaturtha adhyayachedanadi (shleshmahar) varga, Published by Chaukhambha Bharati Academy Reprint 2015. pg no.247,249.

18. Acharya Priyavrat Sharma, Dravyaguna Vigyan, panchamadhyaya deepanadivarga, Published by Chaukhambha Bharati Academy Reprint 2015. pg no.363-365.

19. Acharya Priyavrat Sharma, Dravyaguna Vigyan, navamadhya yajwaraghnadivarga, Published by Chaukhambha Bharati Academy Reprint 2015. pg no.784, 785 .

20. Acharya Priyavrat Sharma, saptamadhyay avrushyadivarga, Published by Chaukhambha Bharati Academy Reprint 2015. pg no.603, 604.

21. Frost CL, Kee NLA, Mnonopi N, Davids H, Nande RJ, Antithrombotic/anticoagulant and anticancer activities of selected medicinal plants from South Africa, African Journal of Biotechnology, 7, 2008, 217-223.

22. Acharya Priyavrat Sharma, Dravyaguna Vigyan, panchamadhyaya deepanadivarga, Published by Chaukhambha Bharati Academy Reprint 2015. pg no. 429,430 .

23. Osoniyi $\mathrm{O}$, Onajobi F, Coagulant and anticoagulant activities in Jatrophacurcas latex, J Ethnopharmacol, 89, 2003, 101-105.

24. Subhadra VD, Christy J, Kumar KA, Maheswari MU, Anticoagulant activity of methanolic bark extract of Careya arborea Roxb., Inter J Pharmaceutical Sci and Biotech, 1, 2010, 93-95.

25. Acharya Priyavrat Sharma, Dravyaguna Vigyan, Navamadhyaya jwaraghnadivarga, Published by Chaukhambha Bharati Academy Reprint 2015. pg no.761.

26. Acharya Priyavrat Sharma, Dravyaguna Vigyan, chaturthaa dhyayachedanadi (kasahar) varga, Published by Chaukhambha Bharati Academy Reprint 2015.pg no.276-279.

27. Acharya Priyavrat Sharma, Dravyaguna Vigyan, panchamadhyaya deepanadivarga, Published by 
Chaukhambha Bharati Academy Reprint 2015. pg no. 429,430 .

28. Acharya Priyavrat Sharma, Dravyaguna Vigyan, navamadhyaya jwaraghnadivarga, Published by Chaukhambha Bharati Academy Reprint 2015. pg no. 833, 834.

29. Acharya Priyavrat Sharma, Dravyaguna Vigyan, navamadhyaya jwaraghnadivarga, Published by Chaukhambha Bharati Academy Reprint 2015. pg no. 831,832 .

30. Ozah B. Triphala: A useful therapeutic supplement during COVID-19 pandemic. JDDT [Internet]. 15Jul.2020 [cited 16Jul.2021]; 10(4):219-20. http: //dx.doi.org/10.22270/jddt.v10i4.4153.

31. Trong TD, Phi HN, Ho KW, Eun HK, Junsoo P, Boo YW, Won KO, Curcuminoids from Curcuma longa and their inhibitory activities on influenza Aneuraminidases, Food Chemistry, Volume 134, Issue 1, 2012, Pages21-28, https://doi.org/ 10.1016 /j.foodchem.2012.02.015

32. https://www.sciencedirect.com/topics/agricultura l-and-biological-sciences/curcuma-longa

33. Kocaadam B, Şanlier N. Curcumin, an active component of turmeric (Curcuma longa), and its effects on health. Crit Rev Food Sci Nutr. 2017 Sep 2 ; 57(13):2889-2895. doi:10.1080/10408398. 2015.1077195.

34. Kizhakkedath, R. Clinical evaluation of a formulation containing Curcuma longa and Boswellia serrata extracts in the management of knee osteoarthritis. Molecular Medicine Reports 8.5 (2013): 1542-1548.https://www.spandidospublications.com $/ \mathrm{mmr} / 8 / 5 / 1542$

35. Raghvendra M.Srivastava, Sarvjeet Singh, ShivK. Dubey, Krishna Misra, Ashok Khar, Immunomodulatory and therapeutic activity of curcumin, International Immuno pharmacology, Volume 11, Issue 3, 2011, Pages 331-341, https:// www. sciencedirect.com/science/article/pii/S15675769 10002687

36. Akhtar S. Use of Tinospora cordifolia in HIV infection. Indian Journal of Pharmacology. 2010; 42(1):57.https://doi.org/10.4103/0253-7613. 62402.

37. Upadhyaya R, Pandey RP, Sharma V, Verma Anita K. Assessment of the multifaceted immunomodulatory potential of the aqueous extract of Tinospora cordifolia. Research Journal of Chemical Sciences. 2011; 1(6):71-79.

38. Mainzen Prince PS, Padmanabhan M, Menon VP. Restoration of antioxidant defense by ethanolic Tinospora cordifolia root extract in alloxan induced diabetic liver and kidney, Phytotherapy Research: An International Journal Devoted to Pharmacological and Toxicological Evaluation of Natural Product Derivatives. 2004; 18(9):785-87. https://doi.org/10.1002/ ptr.1567
39. Aranha I, Clement F, Venkatesh YP. Immunostimulatory properties of the major protein from the stem of the Ayurvedic medicinal herb, guduchi (Tinospora cordifolia).Journal of $\begin{array}{llll}\text { ethnopharmacology. 2012; } 139 & \text { (2):366-72. }\end{array}$ https://doi.org/10.1016/j.jep.2011.11.013

40. Cinatl J, Morgenstern B, Bauer G, Chandra P, Rabenau H, Doerr HW. Glycyrrhizin, an active component of liquorice roots and replication of SARS-associated coronavirus. The Lancet. 2003; 361 (9374): 2045-46. https://doi.org/10.1016/ S0140- 6736(03)13615-X

41. Wang L, Yang R, Yuan B, Liu Y, Liu C. The antiviral and antimicrobial activities of licorice, a widelyused Chinese herb. Acta Pharmaceutica Sinica B. 2015;5(4):310-15.https://doi.org/10.1016/j. apsb. 2015.05.005.

42. Akamatsu H, Komura J, Asada Y, Niwa Y. Mechanism of anti-inflammatory action of glycyrrhizin: effect on neutrophil functions including reactive oxygen species generation. Planta Medica. 1991; 57(02):119-21. https:// doi.org/10.1055/s-2006- 960045

43. Cohen MM. Tulsi- Ocimum sanctum: A herb for all reasons. Journal of Ayurveda and Integrative Medicine. 2014; 5 (4):251-59.

44. Mondal S, Varma S, Bamola VD, Naik SN, Mirdha BR, Padhi MM, Mehta N, Mahapatra SC. Doubleblinded randomized controlled trial for immunomodulatory effects of Tulsi (Ocimum sanctum Linn.) leaf extract on healthy volunteers. Journal of Ethnopharmacology. 2011; 136(3):45256. https://doi.org/10.1016/j.jep.2011.05.01253.

45. Ravi V, Parida S, Desai A, Chandramuki A, Gourie Devi M, Grau- GE. Correlation of tumor necrosis factor levels in the serum and cerebrospinal fluid with clinical outcome in Japanese encephalitis patients. Journal of Medical Virology. 1997; 51(2):132-36.

46. Sangeetha P, Poornamathy JJ. In vitro assessment of anti- inflammatory activity of Ocimum sanctum (karunthulasi leaves). Int Pharma Bio Sci. 2015; 6: B1387-91.

47. Diego Francisco Cortés- Rojas, Claudia Regina Fernandes deSouza, Wanderley Pereira Oliveira, Clove (Syzygium aromaticum): a precious spice, Asian Pacific Journal of Tropical Biomedicine, Volume 4, Issue 2, 2014, Pages 90-96, https:// doi.org/ 10.1016/S2221-1691 (14) 60215-X.

48. Lei W, Xiaoxiao J et al., Piper nigrum extract attenuates food allergy by decreasing Th2 cell response and regulating the Th17/Treg balance, Phytotherapy research, volume 35 , issue $6 /$ p.3214 23225 https://doi.org/10.1002/ptr.7034

49. N Błaszczyk, A Rosiak, J Kałużna-Czaplińska, ThePotential Role of Cinnamon in Human Health 
Forests 2021, 12, 648. https://doi.org/10.3390 /f12050648

50. Samir M, Amrit PS, Medicinal properties of ginger (Zingiber officinale) Natural Product Radiance, volume 2(6), Nov-Dec 2003.

51. Sunila ES, Kuttan G. Immunomodulatory and antitumor activity of Piper longum Linn. and piperine. Journal of Ethnopharmacology. 2004; 90(2-3):339-46.

52. Khushbu C, Roshni S, Anar P, Carol M, Mayuree P. Phytochemical and therapeutic potential of Piper longum Linn. A review. International Journal of Research in Ayurveda and Pharmacy. 2011;2(1): 157-61.

53. Narender Prasad D, B Ganga Rao, E Sambasiva Rao, T Mallikarjuna Rao, V S Praneeth D, Quantification of phytochemical constituents and in-vitro antioxidant activity of Mesua ferrea leaves, Asian Pacific Journal of Tropical Bio medicine, Volume 2, Issue 2, Supplement, 2012, Pages S 539-S542.

\section{Cite this article as:}

Amrut.S. Salunke, Adarsh Ramkalap Sharma, Sonali Sunil Tadasarkar. Role of Ayurvedic anticoagulant and antioxidant treatment in COVID 19. International Journal of Ayurveda and Pharma Research. 2021;9(8):64-70. https://doi.org/10.47070/ijapr.v9i8.1967

\section{*Address for correspondence} Dr. Adarsh Ramkalap Sharma P.G. Scholar Dept. of Shalakyatantra R.A.Podar Medical (AYU) College and M.A. Podar Hospital, Worli, Mumbai.

Contact: 8082229002

Email:

sharmaadarsh808@gmail.com

Disclaimer: IJAPR is solely owned by Mahadev Publications - dedicated to publish quality research, while every effort has been taken to verify the accuracy of the content published in our Journal. IJAPR cannot accept any responsibility or liability for the articles content which are published. The views expressed in articles by our contributing authors are not necessarily those of IJAPR editor or editorial board members. 